Article

\title{
Environmental Sustainability: A Case of Policy Implementation Failure?
}

\author{
Michael Howes ${ }^{1, *}$, Liana Wortley ${ }^{2}$, Ruth Potts ${ }^{3}$, Aysin Dedekorkut-Howes ${ }^{1}$, \\ Silvia Serrao-Neumann ${ }^{4}$, Julie Davidson ${ }^{5}$, Timothy Smith ${ }^{6}$ and Patrick Nunn ${ }^{6}$ \\ 1 Griffith School of Environment and Cities Research Institute, Griffith University, Southport, QLD 4222, \\ Australia; a.dedekorkut@griffith.edu.au \\ 2 Australian Centre of Excellence for Local Governance, University of Technology Sydney, Sydney, \\ NSW 2007, Australia; liana.wortley@griffithuni.edu.au \\ 3 School of Environment, Science, and Engineering, Southern Cross University, East Lismore, NSW 2480, \\ Australia; ruth.potts@scu.edu.au \\ 4 CRC Water Sensitive Cities and Cities Research Institute, Griffith University, Brisbane, QLD 4111, \\ Australia; neumann@griffith.edu.au \\ 5 Discipline of Geography and Spatial Sciences, School of Land and Food, University of Tasmania, \\ Hobart, TAS 7005, Australia; Julie.Davidson@utas.edu.au \\ 6 Sustainability Research Centre, University of the Sunshine Coast, Sippy Downs, QLD 4556, Australia; \\ TSmith5@usc.edu.au (T.S.),pnunn@usc.edu.au (P.N.) \\ * Correspondence: m.howes@griffith.edu.au; Tel.: +61-7-555-27264; Fax: +61-7-555-27785
}

Academic Editor: Marc A. Rosen

Received: 2 December 2016; Accepted: 20 January 2017; Published: 24 January 2017

\begin{abstract}
For a generation, governments around the world have been committed to sustainable development as a policy goal. This has been supported by an array of new policies ranging from international agreements, to national strategies, environmental laws at many levels of government, regional programs, and local plans. Despite these efforts, decades of scientific monitoring indicate that the world is no closer to environmental sustainability and in many respects the situation is getting worse. This paper argues that a significant contributing factor to this situation is policy implementation failure. A systematic review of the literature reveals that the failure to achieve the intended outcomes of environmental policies is due to economic, political and communication factors. Conflict between the objectives of environmental policies and those focused on economic development, a lack of incentives to implement environmental policies, and a failure to communicate objectives to key stakeholders are all key factors that contribute to the inability to attain environmental sustainability.
\end{abstract}

Keywords: environmental policy; sustainable development; environment; environmental governance; environmental outcomes

\section{Introduction}

Sustainability policies have developed and spread from the global to the local level of governance over several decades. The idea of linking environmental, social and economic issues emerged in the 1970 United Nations International Development Strategy and the 1972 UN Conference on the Human Environment in Stockholm. The 1980 World Conservation Strategy introduced the term 'sustainable development' [1] and the concept was elaborated by the World Commission on Environment and Development (WCED), which offered what has become the most commonly used definition: "Sustainable development is development that meets the needs of the present without compromising the ability of future generations to meet their own needs" [2]. This has led to the rise of related concepts 
such as 'Worth-Living Development' that seeks to ensure that "each generation will hand over to the next one a better place to live in" [3]. At the 1992 Rio Earth Summit, 195 national governments agreed to pursue sustainable development via Agenda 21 as well as conventions on biodiversity and climate change (among other arrangements). This international commitment was supported by a myriad of complementary domestic policies that ranged from the national to the local levels of government [4]. Subsequent summits (Rio + 5 (1997), Rio + 10 (2002), and Rio + 20 (2012)) indicated that progress was disappointing, so in 2015 there was a fresh commitment to seventeen Sustainable Development Goals [5] which expanded the Millennium Development Goals through improved social, economic and environmental links [6].

Policies can be assessed against three criteria: effectiveness, efficiency and appropriateness [7], and they are more likely to be successful if they gain social backing [6]. One way of measuring the effectiveness of sustainability policies is to track changes in the state of the environment since their implementation. While there have been some patchy improvements in selected indicators for a few locations [4], the overall decline in environmental quality has continued unabated and no country has achieved environmental sustainability [8-12]. The world's ecological footprint (which measures resource use) exceeded the sustainable capacity of the planet in 1970 and has continued to climb, while the biodiversity index has fallen by more than half $[12,13]$. Emissions of greenhouse gasses are rising and the impacts of global warming are growing [14-16], while the costs of both impacts and mitigation policies face equity issues [17-19]. Air pollution continues to kill millions of people around the world and has worsened recently in parts of south-east and east Asia [20]. Environmental policy failures have been notable in certain industries (such as energy and transport) particularly in developing countries [21-24]. To some extent, this failure to achieve environmental sustainability has prompted the emergence of discussions on the need for a new economic paradigm focused on 'degrowth' [25] and social-ecological transformation [26].

This evidence indicates that the implementation of sustainability policies has contributed to the failure to arrest the overall decline in environmental quality. The question now is why? This paper addresses this question via a systematic quantitative literature review. In the next section, the method used is explained and is then followed by the results, discussion and conclusions. The range of causes, implementation traps, and knowledge/scope issues is identified and analysed. The most common barriers to policy implementation stem from economic and political causes, as well as inadequate communication with key stakeholders.

\section{Methods}

A systematic quantitative literature review was conducted using the methods outlined by Pickering and Byrne [27]. The Scopus database was searched for papers dating up to 2015 that used the terms 'environmental sustainability' and 'policy failure', which resulted in 8339 hits. To limit these results to those papers that would be most relevant, the search was further limited to the terms being found in the article title, abstract or key words in the social sciences and humanities subject area. This returned 125 hits. From this list, papers that met three inclusion criteria were selected. First, selected publications had to address whether environmental sustainability was being achieved. This included research that looked at the success of efforts for achieving environmental sustainability generally and studies that looked at a specific plan, policy or initiative. These policies comprised any area that the authors considered important for environmental sustainability, including water, agriculture and conservation, as well as the environmental impacts of other initiatives such as housing, tourism and transport. Second, selected publications had to identify some kind of failure. This included failing to achieve environmentally sustainable outcomes with current and past initiatives, as well as predicted failings of future initiatives. It also included papers that were developing tools to overcome failings or used predictive models to identify scenarios in which environmental sustainability would or would not be met. A policy was determined to have failed if it did not achieve its environmental 
objectives (as summarised in the introduction to this paper). Finally, selected publications had to identify the cause or causes of the policy failure.

These criteria produced a list of 94 articles in total. The content of these articles was then analysed against the following categories: bibliographic details; data collection methods including whether a case study was included and where it was located; methods to assess sustainability, the environmental issue that was the focus of the paper and the proposed solution; details of the plan/policy/initiative; and, the reason given for the policy failure. The reasons for policy failure were categorised according to the implementation traps synthesised from $[7,28]$. This list was then expanded with new categories that emerged from the content analysis of the articles.

The frequency of publications on environmental policy failure has increased, with a notable increase in publications just prior to and following the Rio +20 summit in 2012. Short-lived bursts of publications also appear to be linked to the Rio +5 (1997) and Rio +10 (2002) summits as well as the release of Intergovernmental Panel on Climate Change Assessment Reports (particularly those released in 2007 and 2013-2014). These findings demonstrate that our review is a timely addition to the academic literature as the failing of environmental policies is clearly a growing concern.

\section{Results}

\subsection{General Trends}

Almost all publications included in their research methods a review of the literature and relevant policies, often supplemented by interviews with key stakeholders ( $20 \%$ of papers reviewed) or surveys (11\%). Some publications modelled official data, such as census statistics $(10 \%)$, and a few utilised focus groups/workshops or comparable methods (4\%). The majority of papers (69\%) utilised a case study to investigate why environmental sustainability had not been achieved. The remainder $(31 \%)$ considered the failure of environmental sustainability in more general or global terms. The case studies covered a diversity of locations including developed and developing countries as well as larger multi-country studies.

Almost half of the papers (48\%) reviewed a specific government policy, plan or strategy. These are presented in Table 1. The remaining papers investigated the failing of environmental policies more generally. All papers related their findings to policy either through the identification of the point at which the application of an individual policy had failed to meet environmental objectives, why environmental sustainability has failed to be addressed by policies, or the barriers to future policies being successfully implemented.

Table 1. Policies analysed by the publications identified through the literature search.

\begin{tabular}{cc}
\hline Specific Policies & Number of Publications \\
International Policies/Agreements/Conventions \\
Agenda 21 \\
United Nation Conference on Environment and Development Statement of Forest Principles 1992 \\
Convention on Biological Diversity \\
Kyoto Protocol \\
Local Agenda 21 \\
Long-Range Transboundary Air Pollution Convention \\
Rio Declaration \\
United Nations Convention on the Law of the Sea (1982) \\
World Soil Charter \\
Convention on the Sustainable Use of Soils \\
Millennium Development Goals \\
UNCED Statement of Forest Principles 1992
\end{tabular}


Table 1. Cont.

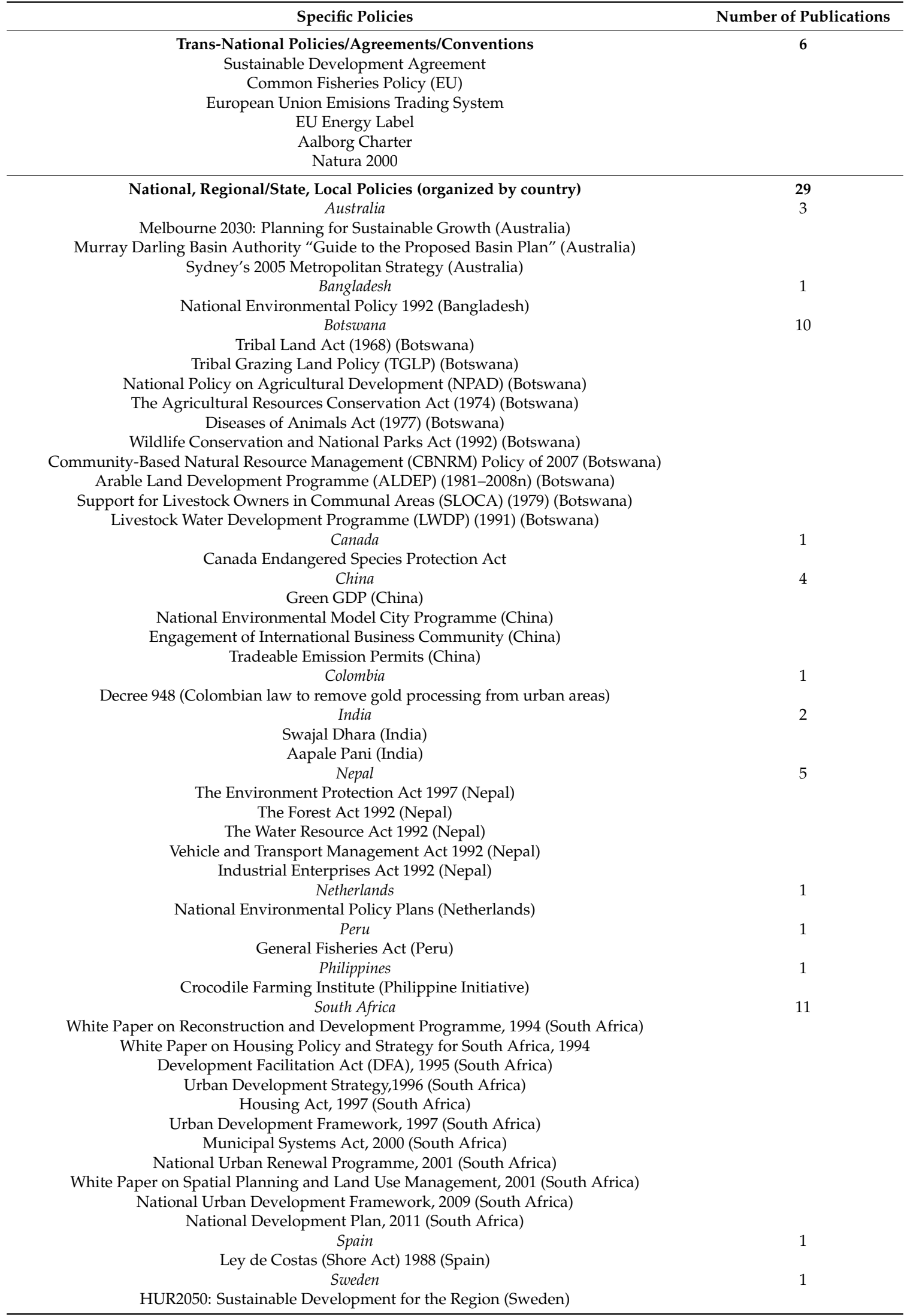


Table 1. Cont.

\begin{tabular}{cc}
\hline Specific Policies & Number of Publications \\
Ukraine & 1 \\
Forests of Ukraine Program & 11 \\
United Kingdom & \\
1990 White Paper: This Common Inheritance (UK) & \\
Sustainable Development, the UK Strategy & \\
Changing Patterns (UK Consumption Strategy) & \\
Government Sponsored Windpower Programme (UK and Denmark) & \\
Local Government Climate Resolution (UK) & \\
Lord Provost's Commission on Sustainable Development (UK) \\
Moving Forward (UK) \\
Producer Responsibility Obligations (Packaging Waste) Regulations 1997 (UK) \\
Packaging (Essential Requirements) Regulations 1998 (UK) \\
Packaging Waste Recovery Note (PRN) system (UK) \\
Urban Taskforce Report (UK) \\
United States of America \\
Clean Air Act (US) \\
Clean Water Act (US) \\
US Pollution Prevention Act \\
Technology Innovation Strategy (US) \\
Project XL (EPA US) \\
Common Sense Initiative (EPA US) \\
Magnuson Fishery Conservation and Management Act (US) \\
\hline
\end{tabular}

\subsection{The Causes of Policy Failure}

The papers included in this review identified numerous causes of policy failure. These can be categorised as structural causes, implementation traps, or knowledge/scope issues. For the purposes of this paper, structural causes are defined as the overarching factors that prevent successful outcomes from being achieved. What defined 'successful outcomes' was determined by the authors of the papers being reviewed and related to the achievement of the objectives of the policy or evidence of improvements in the condition of the environment. The structural causes of failure included economic, social, environmental, political, technical, legal and discursive factors.

Implementation traps were sorted into a set of categories that were developed from Althaus, Bridgman and Davis [7] and Kraft and Kamieniecki [28] and consisted of:

- Incomplete specification of aims or objectives;

- Inappropriate agency for implementation;

- Conflicting objectives within or between policies;

- Incentive failures;

- Conflicting directives from agencies or senior official;

- Limited competence of agency or those tasked with implementation;

- Inadequate administrative resources to support policy implementation; and,

- A failure to communicate with the affected community.

Knowledge or scoping issues included those defined by Patton and Sawicki [29] as theory failure where there was insufficient or poor understanding of the policy issue. As a consequence, the policy instruments used were too narrow or not appropriately targeted. In this category, the lack of evaluation was also included. This relates to knowledge as evaluations build knowledge and learnings to improve policy implementation. The number of papers identified from the review for each failure category is outlined in Table 2. 
Table 2. Reasons for policy failure identified in the literature.

\begin{tabular}{ccc}
\hline & Reasons for Policy Failure & Number of Papers \\
\hline & Economic & 48 \\
Interrelated Structural Causes & Social & 24 \\
& Environmental & 5 \\
& Political & 42 \\
& Technical & 9 \\
& Legal & 32 \\
Implementation Traps & Discursive & 19 \\
& Incomplete specification & 13 \\
& Inappropriate agency & 24 \\
& Conflicting objectives & 30 \\
& Incentive failures & 31 \\
& Conflicting directives & 9 \\
& Limited competence & 21 \\
& Inadequate administrative resources & 22 \\
& Communication failure & 47 \\
\hline \multirow{3}{*}{ Knowledge/scope issues } & A reading of issues that is too narrow & 15 \\
& Lack of Evaluation & 22 \\
& Incomplete understanding of problem & 14 \\
\hline
\end{tabular}

\section{Discussion}

\subsection{Interrelated Structural Causes}

Economic factors, in four broad categories, were cited by 48 publications (51\%) as an underlying cause of policy failure. The first economic cause was a disconnection between economic markets and environmental sustainability, resulting in market failure [30-39]. Dutta [38], for example, argued that the failure to accurately account for environmental and sustainability outcomes in current markets leads "to inefficient allocation of resources, over- or under-production, and only partial fulfilment of environmental goals" [38]. Caviglia-Harris [34] argued that market failure is the cause of over-exploitation of natural resources, and there needs to be better implementation of demand-side policies that promote sustainable products. Pastakia [33] suggested that poorly designed regulations are causing market failure by discouraging investment in, and development of, innovative environmentally sustainable solutions.

The second most common economic cause of policy implementation failure was the favouring of economic outcomes over environmental sustainability [32,40-49]. Rogers and Wilkinson [41] argued that the failure to pass the Canada Endangered Species Protection Act was due to the framing of all discussions in the economic context with commercial interests valued over species protection. Paker et al. [49] found similar results when examining the success of environmentally focused civil society organisations. The authors argued that the state was unwilling to engage with organisations that were at odds with economic priorities and that economic growth was favoured over the implementation of environmental legislation.

The third cause was low levels of economic development and the impacts of development on the environment, particularly in Asia and Africa [37,48,50-58]. As Boadi [53] found, waste disposal, water supply and pollution in the urban areas of Africa were still a significant and growing concern due to poor economic performance limiting the human and material resources available to deal with problems.

Finally, there was a lack of market instruments, and economic markets themselves inhibited the ability to address environmental issues [31,36,40,57,59-76]. Fieldman [76] compared liberal market economies in the UK and USA with coordinated market economies in Germany and Japan in terms of their influence over pollution. The author found that financial liberalisation prevented ecological modernisation (i.e., the decoupling of economic growth from environmental degradation) because 
the market alone did not encourage sufficient environmental innovation. In Ukraine, Soloviy and Cubbage [36] examined the effect of transitioning from a state to market economy on forestry. The author concluded that current forest legislation was incompatible with the market economy and did not prevent illegal harvesting and overexploitation of forests.

Social causes of policy failure were identified in $24(26 \%)$ of the papers analysed. The attitudes/ beliefs of the public were found to influence the successful implementation or adoption of sustainable practices [31,51,61,62,69,77-81]. Social resistance to change was also identified as a significant barrier to policy success $[31,80,82-86]$. In a study of fisheries in the European Union, for example, Carter [80] found that fishermen did not trust scientific estimates for stock depletion and this contributed to overfishing. The characteristics and history of the target community can also influence success $[33,35,36,74,85,87-90]$.

Only five articles (5\%) identified environmental factors as a contributing cause of policy failure. In a study of mining and sustainability in Colombia, for example, Siegel [74], found that geography led to radical regionalisation causing conflict that prevented effective regulation. Unstable or vulnerable environmental conditions were also identified as barriers to success [30,69,78,91]. Mulale et al. [91], for example, found that environmental conditions in certain areas of Botswana make agricultural land particularly vulnerable to desertification/degradation.

Discussions of the underlying political causes of policy failure were found in 42 papers $(45 \%)$. Case studies in Finland, Italy, the West Balkans and Australia indicated that failure may result where policies are not well developed, are not implemented fully, are not politically popular, or go against a prevailing political agenda $[41,47,48,67,71,74,79,92-94]$. Dominant interests, such as extractive industries, may influence what is politically feasible, resulting in a failure to deliver sustainability $[41,42,44,46,49,58,60,73,81,93,95-97]$. An unstable political climate or corruption can further limit success $[37,49,53,56,59,67,74,77,96,98]$. An example was identified by Marcoux and Urpelainen [96], who found that corruption in some Organisation for Economic Cooperation and Development countries led to the overuse of agricultural pesticides. In some cases, authors described environmental issues as becoming highly politicised and thus contentious, leading to policy failure $[44,46,54,78]$. Others argued that changes to existing governance arrangements can be inadequate $[36,42,54,77,85,86,99]$. Finally, a failure to reach an agreement between countries/jurisdictions or reach a decision was identified as a significant barrier to success $[48,68,73,86,88,93,100-106]$.

Only nine papers $(10 \%)$ identified technical limitations as a contributing factor to policy failure. All cited the lack of development or the availability of appropriate technology as a barrier to sustainability $[30,34,38,54,62,69,75,90,107]$. Chen et al. [75], for example, found that there was a need for improved technology in the USA to increase the use of recycled materials in the manufacturing sector. Similarly, Bailey [62] found that less efficient technology led to the lack of recycling of some materials.

Legal factors were identified in 32 papers (34\%). Some authors pointed to the absence of appropriate laws $[32,48,53,59,61,71,74,88,92,99,108-111]$. In other circumstances, legislation was present but either inadequate or not enforced $[36,43,45,46,51,53,62,67,74,109,112]$. A lack of land/property rights was also a significant barrier in the USA, Asia and Africa $[30,34,50,69,98]$. Finally, some laws were actually impediments to achieving environmental targets [33,42,57,67,93]. Buzar [67], for example, found that statutory requirements in the West Balkans were restricting investment in the renewable energy sector.

A further 19 papers $(20 \%)$ identified a range of discursive causes of sustainability policy failure. These included the clash between economic rationalism and environmentalism, as well as the way environmental issues were constructed (as a market failure, for example) [52,58,65,79,80,86,113-115]. The framing of discussion and differences in language used between groups were also found to be impediments $[48,65,81,83,107,116]$. Jabbour et al. [48] identified differences in language use by scientists and policy makers as problematic in progressing towards and achieving international environmental goals. Terms such as 'sustainable development' have also been found to be misnomers and may actually encourage unsustainable behaviour $[46,51,92,117,118]$. 
Failure was rarely due to one isolated factor and was usually linked to a combination of interacting economic, legal and political factors (the three most cited factors). An analysis of the adoption of more sustainable technologies for agriculture in Africa and Asia by Shiferaw, Okello and Reddy [69], for example, found that "policy and institutional failures exacerbate market failures, locking smallholder resource users into a low-level equilibrium that perpetuates poverty and land degradation". Baker et al. [61] looked at the success of national and local initiatives for reducing environmental degradation in Bulgaria and found that an unstable economy, politicisation of the environmental movement, political corruption and an inadequate legal system were preventing successful outcomes from being achieved. Jabbour et al. [48] critically evaluated the progress of international environmental goals from the UNEP (2012) Global Environmental Outlook 5 report [12]. They found that these goals had not been achieved due to the prioritisation of economic growth, the lack of political will, inappropriate governance, a lack of laws, and the different use of language by scientists and policy makers.

\subsection{Implementation Traps}

Incomplete specifications were identified in 13 papers (14\%) as implementation traps. In some cases, policy goals were too vague or broad to be converted into actions $[31,60,84,90,93,98,104,113]$. Voisey and O'Riordan [60], for example, studied the governance arrangements for sustainable development across the UK and found that the specifications of targets contained in the White Paper and strategy were weak, resulting in very limited action. In other circumstances, terms within policies, such as pollution [65] or sedentary species [108], were not clearly defined, preventing successful implementation of the policy $[32,65,92,108]$. Another problem was the lack of guidance within policies on how objectives could be achieved. An example of this was land use and urban greening policies in South Africa that failed largely due to a lack of specific standards or actions [119].

Designating responsibility to inappropriate agencies for policy implementation was identified as a barrier to success in 24 studies $(26 \%)$. This may be the case for a single agency $[31,35,37,45,46,48,60,90,93,102,104]$ or policies that require a multi-level or multi-sector approach to implementation $[36,48,51,59,74,77,98,99,109,110,112]$. Finally, problems also occur when the chain of responsibility for implementing a policy is unclear $[41,48,61,74]$.

Conflicting objectives were cited as an implementation trap in 30 papers (32\%). In some cases, economic development objectives were prioritised over environmental concerns or policies [32,37,41,43-49,52,56,57,60,65,67,73,76,88,90,106,119]. Bromley [65] found that setting pollution targets in the USA resulted in a policy 'lock-in' that was not able to respond to a dynamic market. A lack of coherence between policies and objectives was a problem $[48,87,100,104,113,120]$. Heinzle and Wüstenhagen [120] demonstrated in Germany that revising eco-labelling to accommodate industry demands undermined its effectiveness in informing green consumers.

Incentive failure was identified as an implementation trap in 31 papers (33\%). The majority of these studies cited insufficient incentives to adopt environmentally sustainable practices as a trap and argued for greater economic incentives $[30,32,38,42,45,55,63,66,67,69,74,75,83,84,95,102,117]$. Some found that there were insufficient incentives to implement a policy or comply with regulations as a result of either a lack of official accountability or a lack of public demand for action $[34,36,48,54,60,82,87,108,109]$. Toke [82], for example, found that local communities received little direct benefit from windfarms in the UK and Denmark, resulting in a lack of incentive for their support. Finally, a small number of papers identified circumstances where financial incentives simply failed to achieve the desired outcomes [40,88,91,104,115]. For example, in Botswana, high levels of subsidies for farmers make grazing artificially profitable resulting in overstocking, overgrazing, and consequently environmental degradation [91].

Nine papers (10\%) identified conflicting directives (or orders for action) as implementation traps. A lack of coherence between policy directives and objectives was found to be problematic in the implementation of policies $[34,49-51,68,90,99,104,108]$. Policies identified as having conflicting 
directives include Greece's Natura 2000 [99], the Local Government Climate Resolution in the UK [51], the United Nations Convention on the Law of the Sea [108], and the Magnuson Fishery Conservation and Management Act [108]. In their studies of policies in China and Scotland, Gilley [104] and Mittler [51] found that economic development directives were prioritised over environmental concerns/policies.

Limited or low levels of competence were identified in 21 papers (22\%) as implementation traps. The majority of these papers described examples where those charged with policy implementation lacked sufficient skills, training or knowledge needed for success $[33,37,45,48,53,60,61,69,72,74,77,91,93,96,98,110,119]$. Some studies discussed problems with the transfer of policies or technology to developing countries as a result of limited capacity [55,90,102,119]. Mol [102], for example, found that some developing countries lack the capacity to regulate biofuels. This is a problem because increasing biofuel production may impact on food security and biodiversity as it competes for fertile land.

Inadequate administrative resources were cited in 22 papers $(23 \%)$. In most cases, authors identified an overarching lack of dedicated funding, time, or other resources to achieve environmentally sustainable objectives $[34,36,47,51,53-55,61,69,72,90,93,98,113,119,121]$. In other cases, the tasks required of institutions were found to be beyond the resources allocated to them $[48,49,60,87,110,122]$. Hindmarsh [122], for example, found that water managers in Australia's Murray-Darling river system had insufficient time and resources to conduct adequate consultations, despite statutory requirements to do so.

Four broad forms of communicative failure described in 47 papers $(50 \%)$ topped the list of implementation traps. The first was the inadequacy or absence of consultation with the affected community $[30,41,45,49,56,60,78,79,81-84,94,95,98,99,103,110,115,120,122]$. The second was a failure to adequately involve the community in the policy process $[32,36,57,59,65,73,77,98,104,123]$. The third was community opposition to environmentally sustainable policies/actions $[82,92,93]$. Finally, a lack of community awareness/knowledge of sustainability issues was also identified as a result of communication failure $[33-35,44,51,53,58-60,62,63,74,75,77,87,90,111,113,115]$.

\subsection{Knowledge/Scope Issues}

An incomplete contextual understanding of problems was discussed as an additional cause of policy failure in 15 papers $(16 \%)$ under three broad themes. First was a lack of research into the problem or solution in cases such as energy production, irrigation and food security, carbon dependence, and biosecurity $[55,59,67,114]$. Second, there were misconceptions about the cause of the environmental issues $[48,56,74,91,98,115]$. Finally, there were incomplete or low levels of understanding with regards to the anticipated impacts of policies $[40,45,79,88,107]$.

The breadth and depth of issues encompassed by sustainability was described as a challenge in 22 papers $(23 \%)$. Policies need to be more comprehensive in terms of the area, jurisdiction, or sector covered [31,47,55,59,79,84,88,94,101,104,108,111]. Schuppert [88], for example, concluded that the existing cap and trade systems covered only some sectors, and that climate change-a transboundary problem - requires a global solution, despite such schemes being limited to a few countries. Policy makers also failed to consider or account for the external impacts of sustainability policies $[37,48,54]$. Low levels of policy integration were identified as a contributing factor to policy failure [60,91,98,112,119]. A study of urban greening in housing in South Africa by Shackleton, et al. [119], for example, found that environmental issues were often poorly integrated into urban planning processes and policies. Finally, a number of papers considered that existing policy responses did not have the capacity to meet the challenges posed by sustainability issues $[41,48,60,68,88,91]$.

A lack of evaluation or evaluative mechanisms (measures, targets, or frameworks) was identified as a further barrier to policy success in 14 papers $(15 \%)$. In some cases, such as those involving carbon emissions, there was a total lack of monitoring of outcomes against targets $[31,36,39,60,61,70,84,100,104,111]$. In others, evaluation may have been limited owing to a 
lack of targets or standardised measures [48,54,55,60,64]. Sheppard et al. [55], for example, identified a lack of international biosecurity standards, and Kobus [64] found that there are no standardised measures for sustainable development because of low levels of operationalisation of the concept.

\subsection{Comparison of Policy Failure in Different Contexts}

Of the 94 articles reviewed, $22(23 \%)$ conducted case studies of developing countries (either individual countries or groups of countries), 40 (43\%) conducted case studies of developed countries (individual or groups), and 29 (31\%) had a more general or international focus. Table 3 provides a summary comparison of these clusters and several points stand out (three articles dealt with a mixture of developed and developing countries, and so were not included in Table 3). First, in terms of interrelated structural causes, the two top factors influencing policy failure across the board are economic and political, while legal factors are more predominant in developing countries and discursive issues are more likely to emerge in developed countries. Second, communication failures and conflicting objectives are common, but developing countries are more likely to face problems with all the other implementation traps. Third, developed countries generally have fewer problems with knowledge/scoping issues. Overall, these points are indicative of the differences in the capacity of public sectors, with agencies in developing countries generally being less adequately resourced $[35,63,67,74,97]$.

Table 3. A Comparison of Factors Influencing Policy Failure.

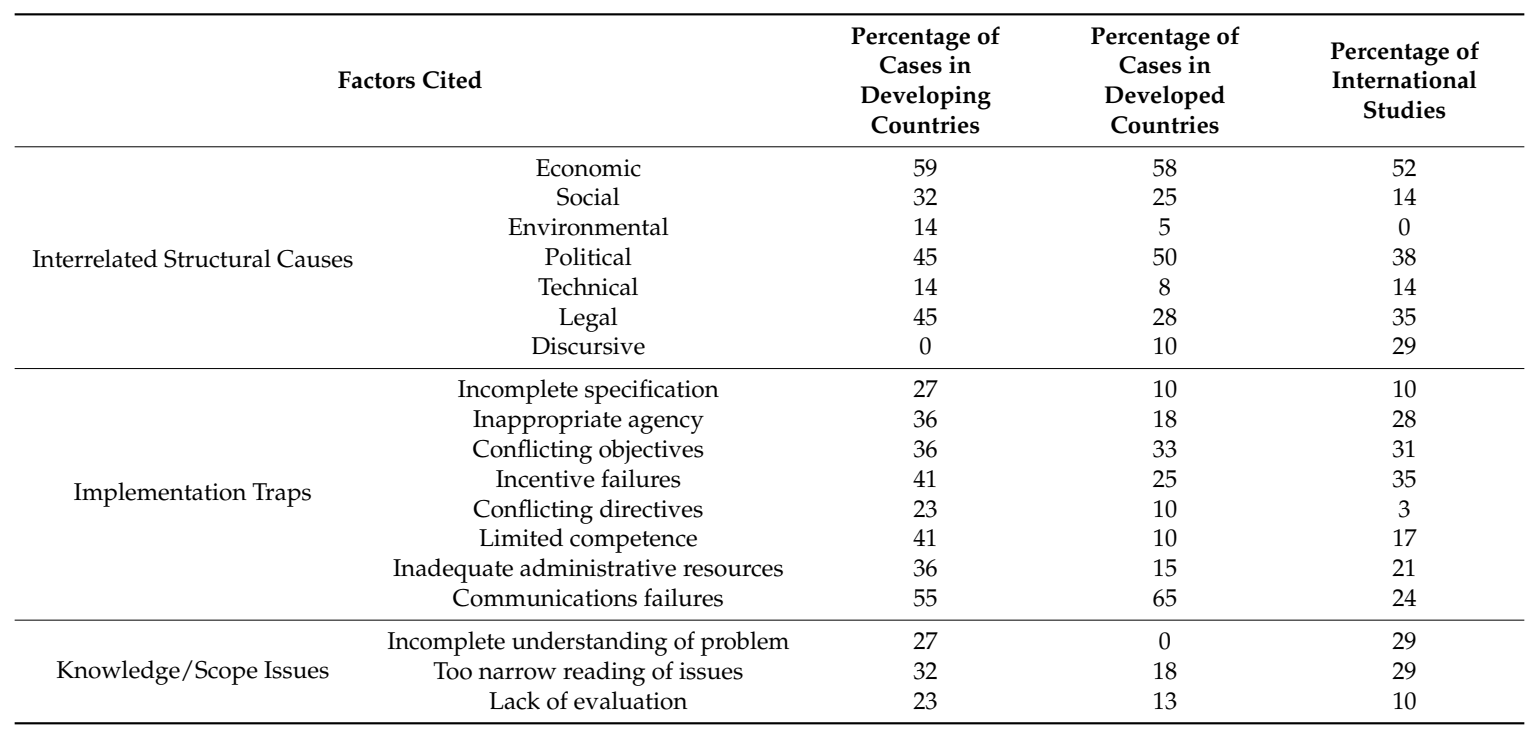

In terms of scale, international initiatives were more prone to discursive issues, largely due to the complexity of international negotiations, but less vulnerable to specific environmental factors due to the general nature of their scope $[100,101,105,106]$. While it is difficult to compare international arrangements to domestic policies, some interesting observations can be made. International initiatives, for example, faced a similar pattern of implementation traps to domestic policies in developed countries, although conflicting directives were less significant because international organisations do not have the same powers as a national or local agency $[102,108,121]$. In terms of knowledge and scoping issues, international initiatives faced similar knowledge/scoping issues as policies in developing countries when it comes to an incomplete understanding of problems.

In terms of the relationships between structural causes, the prevalence of economic and political factors appears in 71 of the 94 papers (76\%), including both the case-study and more general articles. Of these 71 papers, economic and political factors appear together 24 times $(34 \%)$, while economic factors appear independently 29 times (41\%) and political factors 18 times (25\%). Hence, political and economic factors are the predominant causes of policy failures and are clearly linked regardless of 
scale or level of development. Most often, this occurs when economic issues are given political priority over environmental and sustainability issues [32,43-49,57].

\section{Conclusions}

More than two decades have passed since the comprehensive international commitment to pursue sustainable development. Despite the global reach of policies originating from the 1992 Rio Earth Summit, the state of the global environment has continued to deteriorate. Hence, it is clear that these policies have not been sufficient for achieving the goals of sustainability. This paper reviewed 94 different studies on the failure to improve environmental sustainability from many different regions of the world, including both developed and developing countries. Some studies focused on specific cases or policies, others took a more general approach. What is clear from this review is that the inability to improve environmental sustainability is due to a complex number of causes and a significant element is policy implementation failure from the international to the national, regional and local levels of government. The reasons for this failure are a complex set of interrelated structural causes, implementation traps and knowledge/scoping issues.

While the specific reasons for individual policy failures are many and varied, three key factors were recurring. First, there are ongoing economic incentives (supported by policy) for private and public activities to continue to exploit natural resources without deeper consideration of the associated damage to the environment. Second, governments either do not have the capacity and/or the political will to implement effective sustainability policies. Third, the seriousness of sustainability issues and the urgent need for change have not been effectively communicated to key stakeholders. These three factors are mutually reinforcing and suggest that there has been a failure to convince decision-makers in all sectors that sustainable development offers a realistic pathway to a prosperous economy, a better society, and a healthy environment. There are key differences between developed and developing countries with regards to the relative influence of various types of causal factors that lead to policy implementation failures. Developing countries, for example, will face additional challenges with regards to the capacity of their public sector to catalyse change. This means that implementation strategies must be tailored to suit individual situations if they are to be effective.

Having said all this, the past policy implementation failures detailed in the studies that have been reviewed do not indicate that achieving environmental sustainability is impossible [124]. They simply catalogue what has gone wrong with attempts to bring about the necessary change so far. If policy-makers learn from these mistakes, they may still be able to set society on a sustainable development path. The past cannot be changed, but the future is still open for negotiation.

\section{Further Research}

This paper offered a macro-level analysis of the literature on the failure of sustainability policies but a great deal of further research needs to be done. First, it must be acknowledged that more data is needed in order to generate an improved analysis of both the state of the environment and the effectiveness of policies. Second, analyses of individual situations could identify context-specific reasons for failure and explore the complexities in developing and implementing sustainability policies. Third, a micro-level analysis of single issues across different situations would further enrich the analysis. Fourth, tools such as life-cycle analysis, pollution inventories, and more sophisticated biodiversity assessments would be extremely useful. Together these different strands of research should assist in connecting impacts that can be measured to the broader principles of sustainability. 
Acknowledgments: This research was funded by the Commonwealth Government of Australia under the Collaborative Research Network Program and supported by the University of the Sunshine Coast, Griffith University, and the University of Tasmania.

Author Contributions: The idea for this article was conceived at a meeting involving all of the authors. Michael Howes took the lead to organize, guide and supervise the research, analyse the findings, draft and redraft the paper, submit the paper to the journal, and make all changes requested by reviewers. Liana Wortley conducted the initial literature search, sorted the articles found, and assisted with the analysis. Ruth Potts assisted with further analysis and with the rewriting of the paper. Aysin Dedekorkut-Howes, Silvia Serrao-Neumann, Julie Davidson, Timothy Smith and Patrick Nunn all contributed significantly to the analysis and writing of the paper. Timothy Smith also organised funding for the research.

Conflicts of Interest: The authors declare no conflict of interest.

\section{References}

1. International Union for the Conservation of Nature (IUCN); United Nations Environment Programme (UNEP); World Wide Fund for Nature (WWF). World Conservation Strategy; IUCN/UNEP/WWF: Gland, Switzerland, 1980.

2. World Commission on Environment and Development (WCED). Report of the World Commission on Environment and Development: Our Common Future; United Nations: New York, NY, USA, 1987.

3. Kanakoudis, V.; Karatzas, G.; Keramaris, E. International Conference on Efficient \& Sustainable Water Systems Management toward Worth Living Development, 2nd EWaS 2016. Procedia Eng. 2016, 162, 1-2.

4. Howes, M. Politics and the Environment: Risk and the Role of Government and Industry; Allen \& Unwin: Sydney, Australia, 2005.

5. United Nations (UN). Sustainable Development Goals; United Nations: New York, NY, USA, 2015.

6. Fukuda, S.; Murakami, M.; Noda, K.; Oki, T. How Achieving the Millennium Development Goals Increases Subjective Well-Being in Developing Nations. Sustainability 2016, 8, 189. [CrossRef]

7. Althaus, C.; Bridgman, P.; Davis, G. The Australian Policy Handbook, 5th ed.; Allen \& Unwin: Sydney, Austrilia, 2012.

8. Gómez-Baggethun, E.; Naredo, J.M. In search of lost time: The rise and fall of limits to growth in international sustainability policy. Sustain. Sci. 2015, 10, 385-395. [CrossRef]

9. Šoja, S.J.; Anokić, A.; Jelić, D.B.; Maletić, R. Ranking EU Countries According to Their Level of Success in Achieving the Objectives of the Sustainable Development Strategy. Sustainability 2016, 8, 306. [CrossRef]

10. Rockstrom, J.; Steffen, W.; Noone, K.; Persson, A.; Chapin, F.S.; Lambin, E.F.; Lenton, T.M.; Scheffer, M.; Folke, C.; Schellnhuber, H.J.; et al. A safe operating space for humanity. Nature 2009, 461, 472-475. [CrossRef] [PubMed]

11. United Nations Millennium Ecosystem Assessment (UNMEA). Ecosystems and Human Wellbeing: Synthesis Report; Island Press: Washington DC, WA, USA, 2005.

12. United Nations Environment Programme (UNEP). Global Environmental Outlook 5 Report; UNEP: Nairobi, Kenya, 2012.

13. World Wide Fund for Nature (WWF). Living Planet Report 2014: Species and Spaces, People and Places; WWF: Gland, Switzerland, 2014.

14. Intergovernmental Panel on Climate Change (IPCC). Climate Change 2013: The Physical Science Basis; Working Group I Contribution to the Fifth Assessment Report of the Intergovernmental Panel on Climate Change; Cambridge University Press: Cambridge, UK, 2013.

15. Intergovernmental Panel on Climate Change (IPCC). Climate Change 2014: Impacts, Adaptation, and Vulnerability; Working Group II Contribution to the Fifth Assessment Report of the Intergovernmental Panel on Climate Change; Cambridge University Press: Cambridge, UK, 2014.

16. Intergovernmental Panel on Climate Change (IPCC). Climate Change 2014: Mitigation of Climate Change; Working Group III Contribution to the Fifth Assessment Report of the Intergovernmental Panel on Climate Change; Cambridge University Press: Cambridge, UK, 2014.

17. Kanakoudis, V.; Tsitsifli, S.; Papadopoulou, A. Integrating the Carbon and Water Footprints' Costs in the Water Framework Directive 2000/60/EC Full Water Cost Recovery Concept: Basic Principles towards Their Reliable Calculation and Socially Just Allocation. Water 2012, 4, 45-62. [CrossRef] 
18. Kanakoudis, V.; Papadopoulou, A. Allocating the cost of the carbon footprint produced along a supply chain, among the stakeholders involved. J. Water Clim. Chang. 2014, 5, 556-568. [CrossRef]

19. Kanakoudis, V. Three alternative ways to allocate the cost of the CF produced in a water supply and distribution system. Desalinat. Water Treat. 2014, 54, 2212-2222. [CrossRef]

20. World Health Organisation (WHO). WHO Global Urban Ambient Air Pollution Database. Available online: http:/ / www.who.int/phe/health_topics/outdoorair/databases/cities/en/ (accessed on 16 June 2016).

21. Agbonifo, P. Risk Management and Regulatory Failure in the Oil and Gas Industry in Nigeria: Reflections on the Impact of Environmental Degradation in the Niger Delta Region. J. Sustain. Dev. 2016, 9, 126-131. [CrossRef]

22. Hou, Y.; Xu, J. Socialism and Ecological Crises: A View from China. J. Sustain. Dev. 2012, 5. [CrossRef]

23. Enu, D.; Ugwu, U. Human Security and Sustainable Peace Building in Nigeria: The Niger Delta Perspective. J. Sustain. Dev. 2011, 4, 254-259.

24. McGuire, C.; Perivier, H. The Nonexistence of Sustainability in International Maritime Shipping: Issues for Consideration. J. Sustain. Dev. 2011, 4, 72-78. [CrossRef]

25. Asara, V.; Otero, I.; Demaria, F.; Corbera, E. Socially sustainable degrowth as a social-ecological transformation: Repoliticizing sustainability. Sustain. Sci. 2015, 10, 375-384. [CrossRef]

26. Escobar, A. Degrowth, postdevelopment, and transitions: A preliminary conversation. Sustain. Sci. 2015, 10, 451-462. [CrossRef]

27. Pickering, C.M.; Byrne, J. The benefits of publishing systematic quantitative literature reviews for $\mathrm{PhD}$ candidates and other early career researchers. High. Edu. Res. Dev. 2014, 33, 534-548. [CrossRef]

28. Kraft, M.E.; Kamieniecki, S. The Oxford Handbook of U.S. Environmental Policy; Oxford University Press: Oxford, UK, 2012.

29. Patton, C.V.; Sarwicki, D.S. Basic Methods of Policy Analysis and Planning; Prentice Hall: Upper Saddle River, NJ, USA, 1993.

30. Aldy, J.E.; Hrubovcak, J.; Vasavada, U. The role of technology in sustaining agriculture and the environment. Ecol. Econ. 1998, 26, 81-96. [CrossRef]

31. Devkota, S.R. Environment management in Nepal: Unmanaging the manageable. Ecol. Econ. 1999, 28, 31-40.

32. Quesenberry, L. Ecotourism: A hyperbolic sustainable development technique. Dickinson J. Environ. Law Policy 2001, 9, 473-506.

33. Pastakia, A. Assessing ecopreneurship in the context of a developing country: The case of India. Greener Manag. Int. 2002, 38, 93-108. [CrossRef]

34. Caviglia-Harris, J.L.; Kahn, J.R.; Green, T. Demand-side policies for environmental protection and sustainable usage of renewable resources. Ecol. Econ. 2003, 45, 119-132. [CrossRef]

35. Seyfang, G. Shopping for sustainability: Can sustainable consumption promote ecological citizenship? Environ. Politics 2005, 14, 290-306. [CrossRef]

36. Soloviy, I.P.; Cubbage, F.W. Forest policy in aroused society: Ukrainian post-Orange Revolution challenges. For. Policy Econ. 2007, 10, 60-69. [CrossRef]

37. Beeson, M. The coming of environmental authoritarianism. Environ. Politics 2010, 19, 276-294. [CrossRef]

38. Dutta, S.K.; Lawson, R.A.; Marcinko, D.J. Alignment of performance measurement to sustainability objectives: A variance-based framework. J. Account. Public Policy 2013, 32, 456-474. [CrossRef]

39. Hildén, M. Evaluation, assessment, and policy innovation: Exploring the links in relation to emissions trading. Environ. Politics 2014, 23, 839-859. [CrossRef]

40. Tisdell, C. Coevolution, agricultural practices and sustainability: Some major social and ecological issues. Int. J. Agric. Resour. Gov. Ecol. 2000, 1, 6-16. [CrossRef]

41. Rogers, R.A.; Wilkinson, C.J. Policies of extinction: The life and death of Canada's endangered species legislation. Policy Stud. J. 2000, 28, 190-205. [CrossRef]

42. Desrochers, P.; Ikeda, S. On the failure of socialist economies to close the loop on industrial by-products: Insights from the Austrian critique of planning. Environ. Politics 2003, 12, 102-122. [CrossRef]

43. García, G.M.; Pollard, J.; Rodríguez, R.D. The planning and practice of coastal zone management in southern Spain. J. Sustain. Tour. 2003, 11, 204-223. [CrossRef]

44. Parto, S. Sustainability and the local scale: Squaring the peg? Int. J. Sustain. Dev. 2003, 7, 76-97. [CrossRef]

45. Alshuwaikhat, H.M.; Rahman, S.M.; Aina, Y.A. The rationale for SEA to overcome the inadequacy of environmental assessment in Bangladesh. J. Environ. Dev. 2007, 16, 227-246. [CrossRef] 
46. Pelletier, N. Of laws and limits: An ecological economic perspective on redressing the failure of contemporary global environmental governance. Glob. Environ. Chang. 2010, 20, 220-228. [CrossRef]

47. Akgün, A.A.; Van Leeuwen, E.; Nijkamp, P. A systemic perspective on multi-stakeholder sustainable development strategies. Contrib. Confl. Manag. Peace Econ. Dev. 2011, 18, 123-146.

48. Jabbour, J.; Keita-Ouane, F.; Hunsberger, C.; Sánchez-Rodríguez, R.; Gilruth, P.; Patel, N.; Singh, A.; Levy, M.A.; Schwarzer, S. Internationally agreed environmental goals: A critical evaluation of progress. Environ. Dev. 2012, 3, 5-24. [CrossRef]

49. Paker, H.; Adaman, F.; Kadirbeyoğlu, Z.; Özkaynak, B. Environmental organisations in Turkey: Engaging the state and capital. Environ. Politics 2013, 22, 760-778. [CrossRef]

50. Urich, P.B. Could industrialisation and economic growth lead to sustainable environments? Land tenure, population and migration issues in the Philippines. Dev. Bull. Aust. Dev. Stud. Netw. 1998, 45, 52-54.

51. Mittler, D. Environmental space and barriers to local sustainability: Evidence from Edinburgh, Scotland. Local Environ. 1999, 4, 353-365. [CrossRef]

52. Lux, K. The failure of the profit motive. Ecol. Econ. 2003, 44, 1-9. [CrossRef]

53. Boadi, K.; Kuitunen, M.; Raheem, K.; Hanninen, K. Urbanisation without development: Environmental and health implications in African cities. Environ. Dev. Sustain. 2005, 7, 465-500. [CrossRef]

54. Economy, E. Environmental governance: The emerging economic dimension. Environ. Politics 2006, 15, 171-189. [CrossRef]

55. Sheppard, A.W.; Raghu, S.; Begley, C.; Genovesi, P.; De Barro, P.; Tasker, A.; Roberts, B. Biosecurity as an integral part of the new bioeconomy: A path to a more sustainable future. Curr. Opin. Environ. Sustain. 2011, 3, 105-111. [CrossRef]

56. Liu, L. Environmental poverty, a decomposed environmental Kuznets curve, and alternatives: Sustainability lessons from China. Ecol. Econ. 2012, 73, 86-92. [CrossRef]

57. Phelan, L.; McGee, J.; Gordon, R. Cooperative governance: One pathway to a stable-state economy. Environ. Politics 2012, 21, 412-431. [CrossRef]

58. Wright, C.; Nyberg, D. Creative self-destruction: Corporate responses to climate change as political myths. Environ. Politics 2014, 23, 205-223. [CrossRef]

59. Carruthers, I.; Rosegrant, M.W.; Seckler, D. Irrigation and food security in the 21st century. Irrigat. Drain. Syst. 1997, 11, 83-101. [CrossRef]

60. Voisey, H.; O'Riordan, T. Governing institutions for sustainable development: The United Kingdom's national level approach. Environ. Politics 1997, 6, 23-52. [CrossRef]

61. Baker, S.; Baumgartl, B. Bulgaria: Managing the environment in an unstable transition. Environ. Politics 1998, 7, 183-206. [CrossRef]

62. Bailey, I.G. Competition, sustainability and packaging policy in the UK. J. Environ. Plan. Manag. 1999, 42, 83-102. [CrossRef]

63. Ashford, N.A. Government and environmental innovation in Europe and North America. Am. Behav. Sci. 2002, 45, 1417-1434. [CrossRef]

64. Kobus, D. Development and testing of a conceptual framework for assessment of progress towards achieving sustainable development in countries in transition. J. Environ. Assess. Policy Manag. 2005, 7, 457-491. [CrossRef]

65. Bromley, D.W. Environmental regulations and the problem of sustainability: Moving beyond "market failure". Ecol. Econ. 2007, 63, 676-683. [CrossRef]

66. Egli, H.; Steger, T.M. A dynamic model of the environmental Kuznets curve: Turning point and public policy. Environ. Resour. Econ. 2007, 36, 15-34. [CrossRef]

67. Buzar, S. Energy, environment and international financial institutions: The EBRD's activities in the western Balkans. Geogr. Ann. Ser. B Hum. Geogr. 2008, 90, 409-431. [CrossRef]

68. Ooi, G.L. Challenges of sustainability for Asian urbanisation. Curr. Opin. Environ. Sustain. 2009, 1, $187-191$. [CrossRef]

69. Shiferaw, B.A.; Okello, J.; Reddy, R.V. Adoption and adaptation of natural resource management innovations in smallholder agriculture: Reflections on key lessons and best practices. Environ. Dev. Sustain. 2009, 11, 601-619. [CrossRef]

70. Beça, P.; Santos, R. Measuring sustainable welfare: A new approach to the ISEW. Ecol. Econ. 2010, 69, 810-819. [CrossRef] 
71. Polk, M. Institutional capacity-building in urban planning and policy-making for sustainable development: Success or failure? Plan. Pract. Res. 2011, 26, 185-206. [CrossRef]

72. Punter, J. Urban design and the English urban renaissance 1999-2009: A review and preliminary evaluation. J. Urban Des. 2011, 16, 1-41. [CrossRef]

73. Hysing, E. Representative democracy, empowered experts, and citizen participation: Visions of green governing. Environ. Politics 2013, 22, 955-974. [CrossRef]

74. Siegel, S. Community without solidarity: Mercury pollution from small-scale mining and Colombia's crisis of authority. Community Dev. J. 2013, 48, 451-465. [CrossRef]

75. Chen, C.; Liu, L.Q. Pricing and quality decisions and financial incentives for sustainable product design with recycled material content underprice leadership. Int. J. Product. Econ. 2014, 147, 666-677. [CrossRef]

76. Fieldman, G. Financialisation and ecological modernisation. Environ. Politics 2014, 23, 224-242. [CrossRef]

77. Evans, B.; Joas, M.; Sundback, S.; Theobald, K. Governing local sustainability. J. Environ. Plan. Manag. 2006, 49, 849-867. [CrossRef]

78. Bartel, R.; Barclay, E. Motivational postures and compliance with environmental law in Australian agriculture. J. Rural Stud. 2011, 27, 153-170. [CrossRef]

79. Brand, R.; Fischer, J. Overcoming the technophilia/technophobia split in environmental discourse. Environ. Politics 2013, 22, 235-254. [CrossRef]

80. Carter, C.A. Constructing sustainability in EU fisheries: Re-drawing the boundary between science and politics? Environ. Sci. Policy 2013, 30, 26-35. [CrossRef]

81. Lybecker, D.L.; McBeth, M.K.; Kusko, E. Trash or treasure: Recycling narratives and reducing political polarisation. Environ. Politics 2013, 22, 312-332. [CrossRef]

82. Toke, D. Wind power in UK and Denmark: Can rational choice help explain different outcomes? Environ. Politics 2002, 11, 83-100. [CrossRef]

83. Griffin, L. Scales of knowledge: North Sea fisheries governance, the local fisherman and the European scientist. Environ. Politics 2009, 18, 557-575. [CrossRef]

84. Meehan, J.; Bryde, D. Sustainable procurement practice. Bus. Strategy Environ. 2011, 20, 94-106. [CrossRef]

85. Ford, M.; March, A. Assessing the Delivery of Sustainable Residential Development. Int. Plan. Stud. 2012, 17, 1-21. [CrossRef]

86. Blühdorn, I. The governance of unsustainability: Ecology and democracy after the post-democratic turn. Environ. Politics 2013, 22, 16-36. [CrossRef]

87. Williams, J. Sun, surf and sustainable housing-Cohousing, the Californian experience. Int. Plan. Stud. 2005, 10, 145-177. [CrossRef]

88. Schuppert, F. Climate change mitigation and intergenerational justice. Environ. Politics 2011, 20, 303-321. [CrossRef]

89. Thompson, M. Climate, imagination, Kant, and situational awareness. J. Glob. Ethics 2011, 7, 137-147. [CrossRef]

90. Zhang, J.; Liang, X.J. Promoting green ICT in China: A framework based on innovation system approaches. Telecommun. Policy 2012, 36, 997-1013. [CrossRef]

91. Mulale, K.; Chanda, R.; Perkins, J.S.; Magole, L.; Sebego, R.J.; Atlhopheng, J.R.; Mphinyane, W.; Reed, M.S. Formal institutions and their role in promoting sustainable land management in Boteti, Botswana. Land Degrad. Dev. 2014, 25, 80-91. [CrossRef]

92. Connard, C.B. Sustaining agriculture: An examination of current legislation promoting sustainable agriculture as an alternative to conventional farming practices. Penn State Environ. Law Rev. 2004, 13, 125-145.

93. Rinzin, C.; Velthuis, D.N.; Vermeulen, W.J.V. The 'successful failure' of the sustainable development agreement between the Netherlands and Bhutan. Sustain. Dev. 2007, 15, 382-396. [CrossRef]

94. James, S.W. Protecting Sydney's Peri-Urban Agriculture: Moving beyond a Housing/Farming Dichotomy. Geogr. Res. 2013, 52, 377-386. [CrossRef]

95. Pellenbarg, P.H. Sustainable business sites in the Netherlands: A survey of policies and experiences. J. Environ. Plan. Manag. 2002, 45, 59-84. [CrossRef]

96. Marcoux, C.; Urpelainen, J. Special interests, regulatory quality, and the pesticides overload. Rev. Policy Res. 2011, 28, 585-612. [CrossRef] 
97. Upham, P.; Kivimaa, P.; Mickwitz, P.; Åstrand, K. Climate policy innovation: A sociotechnical transitions perspective. Environ. Politics 2014, 23, 774-794. [CrossRef]

98. Chidumayo, E.N.; Gumbo, D.J. The environmental impacts of charcoal production in tropical ecosystems of the world: A synthesis. Energy Sustain. Dev. 2013, 17, 86-94. [CrossRef]

99. Papageorgiou, K.; Vogiatzakis, I.N. Nature protection in Greece: An appraisal of the factors shaping integrative conservation and policy effectiveness. Environ. Sci. Policy 2006, 9, 476-486. [CrossRef]

100. Humphreys, D. The global politics of forest conservation since the UNCED. Environ. Politics 1996, 5, $231-256$. [CrossRef]

101. Bosetti, V.; Buchner, B. Data Envelopment Analysis of different climate policy scenarios. Ecol. Econ. 2009, 68, 1340-1354. [CrossRef]

102. Mol, A.P.J. Environmental authorities and biofuel controversies. Environ. Politics 2010, 19, 61-79. [CrossRef]

103. Oosterlynck, S.; Swyngedouw, E. Noise reduction: The postpolitical quandary of night flights at Brussels Airport. Environ. Plan. A 2010, 42, 1577-1594. [CrossRef]

104. Gilley, B. Authoritarian environmentalism and China's response to climate change. Environ. Politics 2012, 21, 287-307. [CrossRef]

105. Montanarella, L.; Vargas, R. Global governance of soil resources as a necessary condition for sustainable development. Curr. Opin. Environ. Sustain. 2012, 4, 559-564. [CrossRef]

106. Hausknost, D. Decision, choice, solution: 'Agentic deadlock' in environmental politics. Environ. Politics 2014, 23, 357-375. [CrossRef]

107. Allenby, B. Geoengineering: A Critique. In Proceedings of the 2011 IEEE International Symposium on Sustainable Systems and Technology, Chicago, IL, USA, 16-18 May 2011; Institute of Electrical and Electronics Engineers: Chicago, IL, USA, 2011.

108. Von Zharen, W.M. An ecopolicy perspective for sustaining living marine species. Ocean Dev. Int. Law 1999, 30, 1-41. [CrossRef]

109. Ashford, N.A.; Hall, R.P. The importance of regulation-induced innovation for sustainable development. Sustainability 2011, 3, 270-292. [CrossRef]

110. Bogardi, J.J.; Dudgeon, D.; Lawford, R.; Flinkerbusch, E.; Meyn, A.; Pahl-Wostl, C.; Vielhauer, K.; Vörösmarty, C. Water security for a planet under pressure: Interconnected challenges of a changing world call for sustainable solutions. Curr. Opin. Environ. Sustain. 2012, 4, 35-43. [CrossRef]

111. Shokri, A.; Oglethorpe, D.; Nabhani, F. Evaluating sustainability in the UK fast food supply chain: Review of dimensions, awareness and practice. J. Manuf. Technol. Manag. 2013, 25, 1224-1244. [CrossRef]

112. Arias Schreiber, M. The evolution of legal instruments and the sustainability of the Peruvian anchovy fishery. Mar. Policy 2012, 36, 78-89. [CrossRef]

113. Yanarella, E.J.; Bartilow, H. Beyond environmental moralism and policy incrementalism in the global sustainability debate: Case studies and an alternative framework. Sustain. Dev. 2000, 8, 123-134. [CrossRef]

114. Redclift, M. The environment and carbon dependence. Curr. Sociol. 2009, 57, 369-388. [CrossRef]

115. Van der Ploeg, J.; Araño, R.R.; Van Weerd, M. What local people think about crocodiles: Challenging environmental policy narratives in the Philippines. J. Environ. Dev. 2011, 20, 303-328. [CrossRef]

116. Lang, T.; Barling, D. Food security and food sustainability: Reformulating the debate. Geogr. J. 2012, 178, 313-326. [CrossRef]

117. Holden, M.; MacKenzie, J.; Van Wynsberghe, R. Vancouver's promise of the world's first sustainable Olympic Games. Environ. Plan. C Gov. Policy 2008, 26, 882-905. [CrossRef]

118. Benson, M.H. The End of Sustainability. Soc. Nat. Resour. 2014, 27, 777-782. [CrossRef]

119. Shackleton, C.M.; Hebinck, P.; Kaoma, H.; Chishaleshale, M.; Chinyimba, A.; Shackleton, S.E.; Gambiza, J.; Gumbo, D. Low-cost housing developments in South Africa miss the opportunities for household level urban greening. Land Use Policy 2014, 36, 500-509. [CrossRef]

120. Heinzle, S.L.; Wüstenhagen, R. Dynamic adjustment of eco-labelling schemes and consumer choice-The revision of the EU energy label as a missed opportunity? Bus. Strategy Environ. 2012, 21, 60-70. [CrossRef]

121. Waldron, A.; Mooers, A.O.; Miller, D.C.; Nibbelink, N.; Redding, D.; Kuhn, T.S.; Roberts, J.T.; Gittleman, J.L. Targeting global conservation funding to limit immediate biodiversity declines. PNAS 2013, 110, 12144-12148. [CrossRef] [PubMed]

122. Hindmarsh, R. "Liberating" social knowledges for water management, and more broadly environmental management, through "place-change planning". Local Environ. 2012, 17, 1121-1136. [CrossRef] 
123. Brunner, N.; Lele, A.; Starkl, M.; Grassini, L. Water sector reform policy of India: Experiences from case studies in Maharashtra. J. Policy Model. 2010, 32, 544-561. [CrossRef]

124. Elder, M.; Bengtsson, M.; Akenji, L. An Optimistic Analysis of the Means of Implementation for Sustainable Development Goals: Thinking about Goals as Means. Sustainability 2016, 8, 962. [CrossRef]

(c) 2017 by the authors; licensee MDPI, Basel, Switzerland. This article is an open access article distributed under the terms and conditions of the Creative Commons Attribution (CC BY) license (http:/ / creativecommons.org/licenses/by/4.0/). 